\title{
Should recommendations be made to reduce dietary sodium intake? The case for recommendations
}

\author{
By D. G. Beevers, Department of Medicine, Dudley Road Hospital, Birmingham \\ $B 187 Q H$
}

I do not actually disagree with anything that Dr Lever has said, but for the purposes of this debate I have the task of opposing him. The answer I think will probably prove to be somewhere between the two of us. I will review very briefly the epidemiological evidence that a relation exists between sodium intake and blood pressure when comparing populations. I do not deny that there are problems with comparisons between primitive tribesmen, Japanese fishermen and Chicago businessmen. However, if one looks at studies which show a wide spectrum of $\mathrm{Na}$ intake and blood pressure, then there clearly is a relation (Lever et al. 1981). It is probably not valid to plot graphs in which many different population surveys, conducted at different times using different methods are compared, and a more reliable single study is needed. Such a project (the Intersalt project) is now in hand in which blood pressure, salt excretion and all the possible confounding variables are being measured in fifty-eight populations across the world using identical methodology. Results should be available by 1987 .

We should not consider $\mathrm{Na}$ intake in isolation. One cannot possibly dissociate dietary $\mathrm{Na}$ from dietary potassium intake as it is difficult to manipulate one without the other. As an example I would mention a comparison of the populations of Leuven, Belgium, and Renfrew, Scotland (Hawthorne et al. 1974; Staesson et al. $198 \mathrm{r}$ ). The studies were more or less identical in terms of methods, but the population of Leuven had lower blood pressures than the Scots and they had a slightly lower $\mathrm{Na}$ excretion. It is important to note, however, that the Leuven population had roughly twice the $\mathrm{K}$ excretion of the Scots.

We certainly must be careful when analysing international comparisons showing a relation between $\mathrm{Na}$ intake and blood pressure and I dislike any hypothesis that relies on the epidemiological extremes. However, when we do compare a low and a high salt-intake society we see a striking difference in the way that blood pressure is distributed. In the primitive populations there is virtually no rise in blood pressure with age, and hypertension is rare. When we compare Professor Sever's studies in rural Africa (Poulter et al. 1984) with the Renfrew community (Beevers et al. 1980) we see a difference in the whole distribution of blood pressure. If the distribution curve for Renfrew could be shifted to the left to resemble that seen in Kenya then hypertension and its sequelae would almost cease to be a public-health problem. 
The argument that reducing dietary $\mathrm{Na}$ intake is no more effective than drugs needs to be put into context. Stroke mortality has been falling steadily over more than $5^{\circ}$ years in Britain but the introduction of antihypertensive therapy in the 1960 s has made little or no impact on this decline. Stroke mortality was falling long before methyldopa and similar drugs had been heard of. Something was happening before drug treatment of hypertension became available. The answer almost certainly is that dietary $\mathrm{Na}$ has been steadily falling ever since the introduction of the refrigerator. We no longer need to add so much salt to our food to preserve it.

Turning to the evidence from rat experiments cited by Dr Lever, my own view about rat work is that some rats develop hypertension and that some do not. To quote Jimmy Reid, former Rector of the University of Glasgow, 'we are not rats'.

I would next like to turn to evidence for the link between $\mathrm{Na}$ intake and blood pressure in longitudinal studies which are either natural experiments or intentional intervention trials. The natural experiments are those of migrants and have largely taken place in Africa. Professor Sever has compared rural and urban Xausa tribesmen (Sever et al. 1980). They do not change their genes when they migrate to the city, but they do increase their salt intake and reduce their $\mathrm{K}$ intake. More recently, a study of Luo tribesmen conducted by Poulter in Kenya has followed the changes in blood pressure of migrants from Lake Victoria as they move to the shanty towns on the edge of Nairobi (Poulter et al. I984). There was a dramatic rise in blood pressure as soon as they reached the town, which was associated with a doubling of $\mathrm{Na}$ intake and a marked reduction of $\mathrm{K}$ intake. The only significant confounding variable in this study was the consumption of alcohol which may have risen in the city dwellers. This could also have caused a rise in blood pressure. Natural studies conducted in Japan are illuminating. The Japanese consume very high salt diets (up to $400 \mathrm{mmol} / \mathrm{d}$ ) whereas in England we would probably eat around $150 \mathrm{mmol} / \mathrm{d}$. The stroke incidence in North Japan is very high, much higher than that in Scotland, but there is a natural experiment occurring in Japan in that salt intake is falling steadily and so is stroke mortality.

There is evidence from short-term experiments that when $\mathrm{Na}$ intake is reduced in hypertensives, the blood pressure falls (MacGregor et al. 1982). A study from Wales by Watt et al. (1983) is claimed to be a study of hypertensives and is regarded as being negative. However, I argue that this was not a study of hypertensives as their diastolic blood pressures were only $82 \mathrm{~mm} \mathrm{Hg}$. A 2 week period of salt depletion appeared to have little effect on blood pressure in normotensive subjects.

An important study is that of Hofman et al. ( 1983$)$. This was a well conducted trial in which babies were randomized to receive a normal or low salt food diet from birth. At the end of 25 weeks blood pressures were significantly lower in the babies on the low-salt diet, but I would stress that they were not severely $\mathrm{Na}$ depleted. It may be argued that this difference $(2 \mathrm{~mm} \mathrm{Hg})$ was biologically insignificant, but the difference was seen at 25 weeks of age. One can only speculate what would happen over the ensuing years, but one would hope that if 
dietary $\mathrm{Na}$ remained restricted, hypertension would become less common.

There is also another well conducted study which shows the link between $\mathrm{Na}$ intake and blood pressure (Stamler et al. 1984). There were three groups of subjects all of whom had been receiving antihypertensive drug treatment and had good blood pressure control. One-third of these subjects had their tablets stopped, another third also had their tablets stopped but were also given intensive dietary advice and the third group of patients continued their treatment. Blood pressures rose in the group which stopped treatment, blood pressures remained unchanged in the group which continued treatment. Those patients who stopped their therapy but also received dietary advice tended to maintain lower blood pressures than those who received no dietary advice.

Let us now speculate what might happen if we lowered salt intake on a national basis. I think only a relatively small reduction in $\mathrm{Na}$ intake is necessary. The average salt intake in England is around $150 \mathrm{mmol} / \mathrm{d}$. The saltiest diet in this country was in Renfrew with an average value of $190 \mathrm{mmol} / \mathrm{d}$ and the population of Glasgow has the highest stroke incidence in the UK and possibly in Europe. I am arguing for a reduction in salt intake from that in the average Renfrew diet to something more like that seen in Southern Europe. I am not asking for intense salt depletion to a level that makes people unwell. I do not deny that salt is needed in food. I would also stress that $\mathrm{Na}$ intake cannot be considered without $\mathrm{K}$ intake and I would suggest that this can be achieved by substitution of high-K foods for high-salt foods. If we are interested in reducing the blood pressure of the whole population then a whole population strategy is necessary. Clinical medicine has failed to make any major impact on blood pressure or coronary heart disease in Britain. If we were to reduce the salt intake of the whole population there would be a shift in the bell shaped distribution curve to lower ranges and we would dramatically reduce the blood pressures of the population as well as that of hypertensive patients and thereby prevent thousands of deaths. The alternative possibility, however, which I think is interesting, is that salt depletion in the population would only 'normalize' the Gaussian distribution curve of blood pressures which at present is skewed towards higher levels. By doing this, however, we would also abolish hypertension and about $20 \%$ of the population would benefit from this manoeuvre. However, as I have already mentioned in connection with the Hofman et al. (1983) study, maintaining a low salt intake from very early life might well prevent the development of hypertension in the first place and this is a very attractive option.

I would next like to argue against the view that harm may come from lowering salt intake. This argument is usually stated by clinicians who give their patients angiotensin-converting enzyme inhibitors which cause neutropenia, rashes and loss of taste. They also give them Ca-channel blockers and $\beta$-blockers all of which have side effects. However, these clinicians may have wives who routinely cook good food with a salt content similar to that which I am advocating. They do not eat horrible salt-laden junk food. The differences in salt intake which are seen in the UK are probably closely associated with social class although I cannot prove this. 
In cafes and lorry-drivers' 'pull-ins' salt is added in enormous quantities to the food. I am asking only for a change in the salt intake to one which is in the range that many people in this room are already consuming, that is to around $100 \mathrm{mmol}$ $\mathrm{Na} / \mathrm{d}$.

\section{REFERENCES}

Beevers, D. G., Hawthorne, V. M. \& Padfield, P. L. (1980). British Medical Fournal 281, $641-642$.

Hawthorne, V. M., Greaves, D. A. \& Beevers, D. G. (1974). British Medical fournal 3, 600-603.

Hofman, A., Hazebrock, A. \& Valkenburg, H. A. (1983). Yournal of the American Medical Association 250, 370-373.

Lever, A. F., Beretta-Picolli, C., Brown, J. J., Davies, D. L., Fraser, R. \& Robertson, J. I. S. (1981). British Medical Yournal 283, 463-468.

MacGregor, G. A., Markandu, N. D., Best, F. E., Elder, D. M., Cam, J. M., Sagnella, G. A. \& Squires, M. (1982). Lancet i, $351-354$.

Poulter, N., Khaw, K.-T., Hopwood, B. E., Mugambi, M., Peart, W. J., Rose, G. \& Sever, P. S. (Ig84). Foumal of Epidemiology and Community Health 38, 181-185.

Sever, P. S., Gordon, D., Peart, W. J. \& Beighton, P. (1980). Lancet ii, 60-69.

Staesson, J., Fagard, R., Lijnen, P., Amery, A., Bulpitt, C. \& Joossens, J. V. (1981). Jourmal of Epidemiology and Community Health 35, 256-26r.

Stamler, R., Stamler, J., Grimm, R., Gosch, F., Dyer, A., Berman, R., Civinelli, J., Elmer, P., Fishman, J., Van Heel, N., McDonald, A. \& McKeever, P. (1984). Journal of Hypertension 2, Suppl. 3, 167-170.

Watt, G. C. M., Edwards, C., Hart, J. T., Hart, M., Walton, P. \& Foy, C. J. W. (1983). British Medical fournal 286, $432-436$. 